\title{
Influence of Irrigation Volume and Mulch on Establishment of Select Shrub Species
}

\author{
Thayne Montague, Cynthia McKenney, Michael Maurer, and Brian Winn
}

\begin{abstract}
In many climates, irrigating shrubs during establishment is critical for long-term growth and survival. However, little research has been conducted to investigate irrigation requirements of newly transplanted container-grown shrubs. During two growing seasons, we investigated gas exchange and growth of newly planted container-grown crapemyrtle (Lagerstroemia indica 'Victor'), forsythia (Forsythia $\times$ intermedia 'Lynwood'), Vanhoutte spirea (Spiraea $\times$ vanhouttei), and photinia (Photinia $\times$ fraseri) transplants placed into landscape beds with and without organic mulch. After transplanting, plants were irrigated twice each week at the following rates: $100 \%, 75 \%$, and $50 \%$ of reference evapotranspiration (ETO). In general, each year, transplants with mulch and transplants receiving $100 \%$ or $75 \%$ ETO-based irrigation had greater stomatal conductance when compared with transplants without mulch and transplants receiving less irrigation. Growth of transplants followed similar trends. However, it is key to note all transplants survived and appeared healthy throughout the growing season. Even transplants receiving 50\% ETO were aesthetically pleasing and had growth acceptable for landscape situations. These findings should be useful for landscape irrigation scheduling and for irrigation managers incorporating water conservation into their landscape maintenance programs.
\end{abstract}

Key Words. Forsythia $\times$ intermedia; Lagerstroemia indica; Photinia $\times$ fraseri; reference evapotranspiration; Spiraea $\times$ vanhouttei; transplant.

In many communities, urban landscape irrigation is a large fraction of total water use. In fact, in arid regions of the United States, landscape irrigation is estimated to consume $40 \%$ or more of all residential water used in urban communities (Ferguson 1987). Depletion of water tables (Jensen et al. 1997), poor water quality (McDaniels et al. 1998), and drought (Urbano 1990) have emphasized the need for many communities to implement water conservation programs (Stabler and Martin 2000; Spinti et al. 2004). However, these programs are often implemented without regard to plant water requirements. Therefore, although landscape irrigation is often required, a challenge confronting irrigation managers is to conserve water while meeting the water requirements of landscape plants (Stabler and Martin 2000).

Reduced soil moisture evaporation is one of the benefits organic mulch (pine bark, pruning chips, pine needles, and so on) may produce in landscapes (Greenly and Rakow 1995; Montague et al. 2000a). Nevertheless, research on growth of woody landscape plants surrounded by organic mulch has been inconsistent. Many authors report growth of woody plants was not influenced or was reduced by organic mulch (Whitcomb 1980; Litzow and Pellett 1983; Hild and Morgan 1993; Kraus 1998; Montague et al. 2000a; Arnold et al. 2005). However, several researchers indicate woody plants surrounded by organic mulch had enhanced apical (Fraedrich and Ham 1982; Hensley et al. 1988) and root growth (Watson 1988; Watson and Kupkowski 1991) when compared with woody landscape plants grown without mulch.

Costello and Paul (1975) found container-grown plants often fail to establish in the landscape because of rootball desiccation and associated water stress. Rootball desiccation may occur for several reasons. First, containerized plants in a production nursery are irrigated at least once each day, whereas newly transplanted containerized plants generally have a much lower irrigation frequency (Costello and Paul 1975). In addition, there is a limited amount of available water in the rootball of a newly transplanted container-grown plant. Transplants cannot take up moisture from outside the rootball until roots establish into the surrounding soil (Wright et al. 2004). Quick root growth into the soil is critical for survival of container-grown plants (Arnold et al. 2005). However, for many woody container-grown groundcover and shrub species, research on plant water use (gas exchange) has been conducted only after plants have become established in the landscape (Sachs et al. 1975; Paine et al. 1992; Staats and Klett 1995; Pittenger et al. 2001; Shaw and Pittenger 2004).

Early and successful growth of a container plant's root system into the soil after transplanting would greatly increase 
survivability and establishment (Kraus 1998). However, environmental factors can increase plant stress and delay establishment of woody plants in landscapes (Montague et al. 2000b). Little information is available on whether organic mulch influences gas exchange and establishment of newly transplanted containerized shrub species. In addition, information is lacking on the amount of water required to establish container-grown woody shrub species in landscapes. Therefore, this research was conducted to document plant gas exchange and growth of four container-grown shrub species exposed to three irrigation levels and soil surfaces covered with organic mulch or left bare.

\section{MATERIALS AND METHODS}

Research was conducted in field plots over two growing seasons (2001 and 2002) at the Texas A\&M research and Extension Center in Dallas, Texas, U.S. Each year, nine landscape plots were used. Each whole plot $(3 \mathrm{~m} \times 4 \mathrm{~m}[9.9 \mathrm{ft} \times$ $13.2 \mathrm{ft}])$ was constructed with timber frames $(10 \mathrm{~cm} \times 10 \mathrm{~cm}$ $\times 3 \mathrm{~m} \mathrm{[4}$ in $\times 4$ in $\times 9.9 \mathrm{ft}])$ around each plot. Using corrugated sheet fiberglass (buried $30 \mathrm{~cm}$ [12 in]) below soil level and raised $30 \mathrm{~cm}$ [12 in] above soil level), each plot was further divided in half into two subplots (forming 18 subplots). Soil consisted of an Austin silty clay (fine-silty, carbonatic, thermic Udorthentic Haplustolls). Drip irrigation (model R17-35B030; Netafim Inc., Fresno, CA) was installed on a $30 \mathrm{~cm}$ (12 in) grid inside each plot. Irrigation tubing was equipped with one $3.8 \mathrm{~L} / \mathrm{h}^{-1}\left(1 \mathrm{gal} / \mathrm{h}^{-1}\right)$ pressurecompensating emitter every $30 \mathrm{~cm}$ (12 in). Each whole plot was fitted with one flow meter (model Bermadon MTA; Bermad Inc., Anaheim, CA) and a $138 \mathrm{kPa}(20 \mathrm{psi})$ pressure regulator (model PMR 20 MF; Senninger Irrigation, Inc., Orlando, FL). An automated weather station (Model Metdata1; Campbell Scientific, Inc., Logan, UT) located on the experiment site was used to monitor weather conditions. Data received from this weather station were used to calculate weekly cool-season grass reference evapotranspiration (ETO). Grass reference ETO was calculated using ETO calculation software (Allen 2000). Irrigation to each plot was applied twice each week at three rates: 100\% ETO (high), 75\% ETO (medium), and 50\% ETO (low) replacement rates (based on total ETO [mm] for the previous 3 or 4 days and plot area $\left[\mathrm{m}^{2}\right]$. Before irrigation calculations, daily precipitation depth was subtracted from total ETO.

Mid-May 2001 and 2002, three uniform plants of four different woody shrub species commonly grown in the region were planted in each plot. All plants were selected from a local nursery and were grown in $3.8 \mathrm{~L}$ (1 gal) containers. Species included crapemyrtle (Lagerstroemia indica 'Victor'), forsythia (Forsythia $\times$ intermedia 'Lynwood'), photinia $($ Photinia $\times$ fraseri), and Vanhoutte spirea (Spiraea $\times$ vanhouttei). Shrubs were planted in rows (three plants of the same species in each row and four rows in each plot) $60 \mathrm{~cm}$
(24 in) apart. Within each subplot, species were randomly assigned to each row. After planting, $10 \mathrm{~cm}$ (4 in) of cypress bark mulch (shredded, 7.6 to $10 \mathrm{~cm}$ [3 to $4 \mathrm{in}$ ] long) was placed on one randomly selected subplot of each whole plot. Mulch was maintained at this height throughout the experiment and weeds that appeared after planting were removed by hand. Throughout the experiment, pruning was not performed and fertilizer was not applied.

Throughout each growing season, midday stomatal conductance (GS) was measured each week. Measurements were taken twice each week (two species each day) on the same day but before application of irrigation. Midday GS was measured on three recently mature full sun leaves from two randomly selected plants of each species within each subplot. Midday GS measurements began at 1200 P.M. each day. Midday GS was measured with a steady-state porometer (Model 1600; LI-COR Inc., Lincoln, NE). Midday GS measurements began with the random selection of one subplot. Measurements were made on two species within the selected subplot and then another subplot was randomly selected. Midday GS concluded each day around 230 P.M. At the conclusion of each year's experiment (1 October), each plant was carefully uprooted and prepared for dry mass analysis. Soil was washed from roots and when clean of soil particles, roots and shoots of each plant were placed in separate paper bags and placed in a drying room. Plant material was dried at $70^{\circ} \mathrm{C}$ $\left(158^{\circ} \mathrm{F}\right)$ for 1 week and weighed.

Each species was treated as a separate experiment (Arnold et al. 2005); therefore, species comparisons were not statistically analyzed. Midday GS and growth data of each species were subjected to analysis of variance appropriate for a split plot design (large plot $=$ whole plot, mulch treatment $=$ split plot) arranged in completely randomized blocks with three irrigation levels and two mulch treatments for each species. Therefore, there were three blocks and each block contained three plants of each species/irrigation/mulch combination (nine plants for each species/irrigation/mulch treatment). Data were analyzed using the general linear models procedures in the SAS System for Windows (release 8.01; SAS Institute, Inc., Cary, NC). For each species, there were no irrigation/mulch treatment interactions. Therefore, only main effect data are presented. Midday GS for each species/ irrigation treatment combination was taken as the mean of 18 measurements and midday GS for each species/mulch treatment combination was taken as the mean of 27 measurements. Midday GS data were plotted against weeks after transplanting (WAT). For growth data, if significant differences were found, means were separated by Fisher's least significance difference procedure $(P \leq 0.05)$. Daily midday GS and shoot and root mass data from each season produced similar results. Therefore, only data from the 2001 growing season are presented. 


\section{RESULTS}

Climatic data for the growing period were typical for summer days in Central Texas. For the experimental period, average daily maximum temperature was $32.1^{\circ} \mathrm{C}\left(89.8^{\circ} \mathrm{F}\right)$ and total precipitation was $26.3 \mathrm{~cm}$ (10.5 in) (Figure 1). For the experiment period, average daily wind speed was $3.1 \mathrm{~m} / \mathrm{s}^{-1}(6.3$ $\mathrm{mph}$ ), average daily total shortwave irradiance was $19.6 \mathrm{MJ} /$ $\mathrm{m}^{-2}$, and relative humidity $(\mathrm{RH})$ was variable (minimum daily $\mathrm{RH}$ ranged from $92 \%$ to $14 \%$ ) (data not presented). Because of these climatic variables, total daily ETO ranged from 1.2 to $9.5 \mathrm{~mm}^{\text {-day }}$ ( 0.05 to $\left.0.38 \mathrm{in}^{\text {-day }}\right)$, and average ETO for the experiment period was $5.8 \mathrm{~mm}^{- \text {day }}\left(0.23 \mathrm{in}^{\text {-day }}\right)$ (Figure 1). Irrigation totals for each plot were 6,875 L (1788 gal), 5,156 L (1341 gal), and 3,438 L (894 gal) for high, medium, and low irrigation treatments, respectively.

Throughout the growing season, all transplants survived and appeared healthy. After transplanting, midday GS for all transplants was low (near $20 \mathrm{mmol} / \mathrm{m}^{-2} / \mathrm{s}^{-1}$ ) but gradually increased until WAT 8, when GS for each species was generally the greatest (Figures 2-5). However, after WAT 8, GS for each species generally declined. Late in the growing season for crapemyrtle transplants, midday GS was influenced by irrigation level and mulch (Figure 2). Greater midday GS was generally found on transplants receiving high and medium irrigation treatments and transplants with mulch (Figure 2). Data also indicate irrigation level and mulch influenced crapemyrtle root and shoot mass. Plants with mulch and plants receiving medium and high irrigation treatments had greater mass when compared with plants receiving the low irrigation treatment (Figure 2). Throughout the growing season, midday GS of spirea transplants was influenced by irrigation treatments and mulch in a similar manner as crapemyrtle (Figure 3). For spirea transplants, growth data indicate greater irrigation levels and mulch increased root and shoot

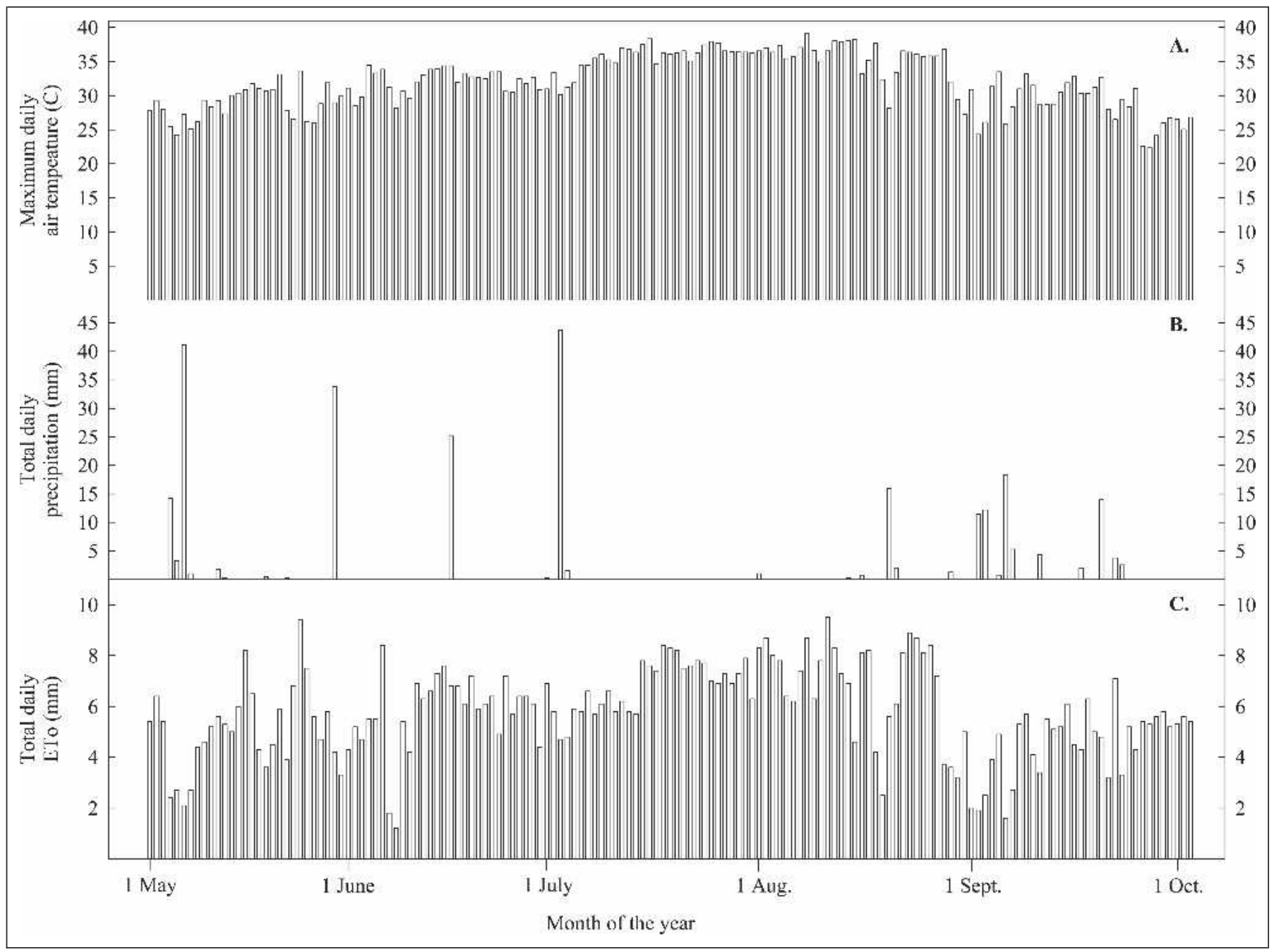

Figure 1. (A) Maximum daily air temperature, (B) total daily precipitation, and (C) total daily evapotranspiration (ETO) for Dallas, Texas, U.S. during the 2001 growing season (1 May through 30 September). 


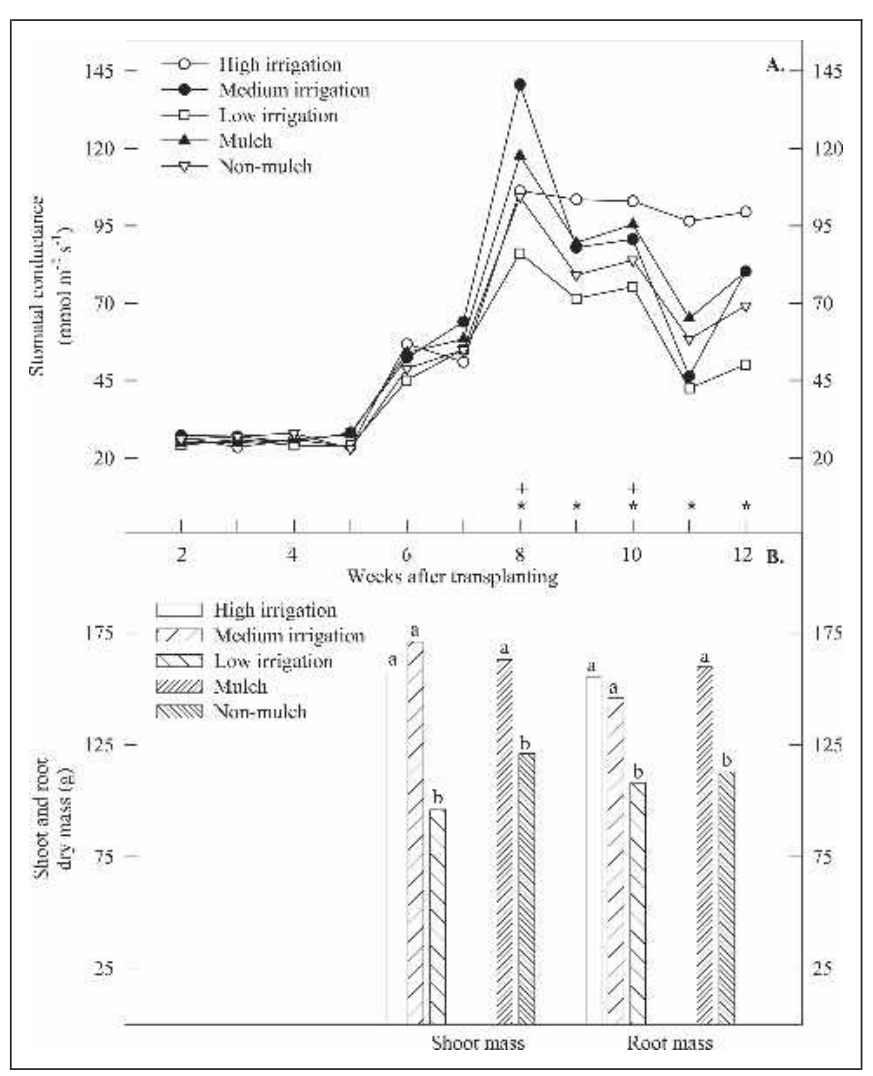

Figure 2. Effect of irrigation volume and mulch on (A) stomatal conductance and (B) growth of containerized crapemyrtle (Lagerstroemia indica 'Victor') transplants grown in Dallas, Texas, during 2001. Asterisks or plus signs (A) indicate treatment effects at the $1 \%, 5 \%$, or $10 \%$ level by $\mathrm{F}$ test for irrigation volume and mulch, respectively (each point is the mean of 18 (irrigation treatment) or 27 (mulch treatment) measurements). Different letters (B) indicate effect of irrigation volume or mulch on plant growth (least significant difference, $P \leq 0.05$ ).

mass (Figure 3). Forsythia transplants receiving greater irrigation generally had greater midday GS than transplants at the low irrigation level (Figure 4). Forsythia transplants also appear to be very responsive to mulch. Midday GS of forsythia transplants was influenced more frequently by mulch than any other species. Shoot and root mass of forsythia transplants was greatest for plants that received the high irrigation treatment and were surrounded by mulch (Figure 4). From WAT 7, photinia transplants with high irrigation generally had greater midday GS when compared with photinia transplants receiving medium or low irrigation treatments (Figure 5). However, mulch influenced midday GS of photinia transplants on only two occasions (WAT 7 and 8). Differences in shoot mass indicate photinia transplants with medium and high irrigation had greater mass when compared with transplants with low irrigation (Figure 5). Root mass

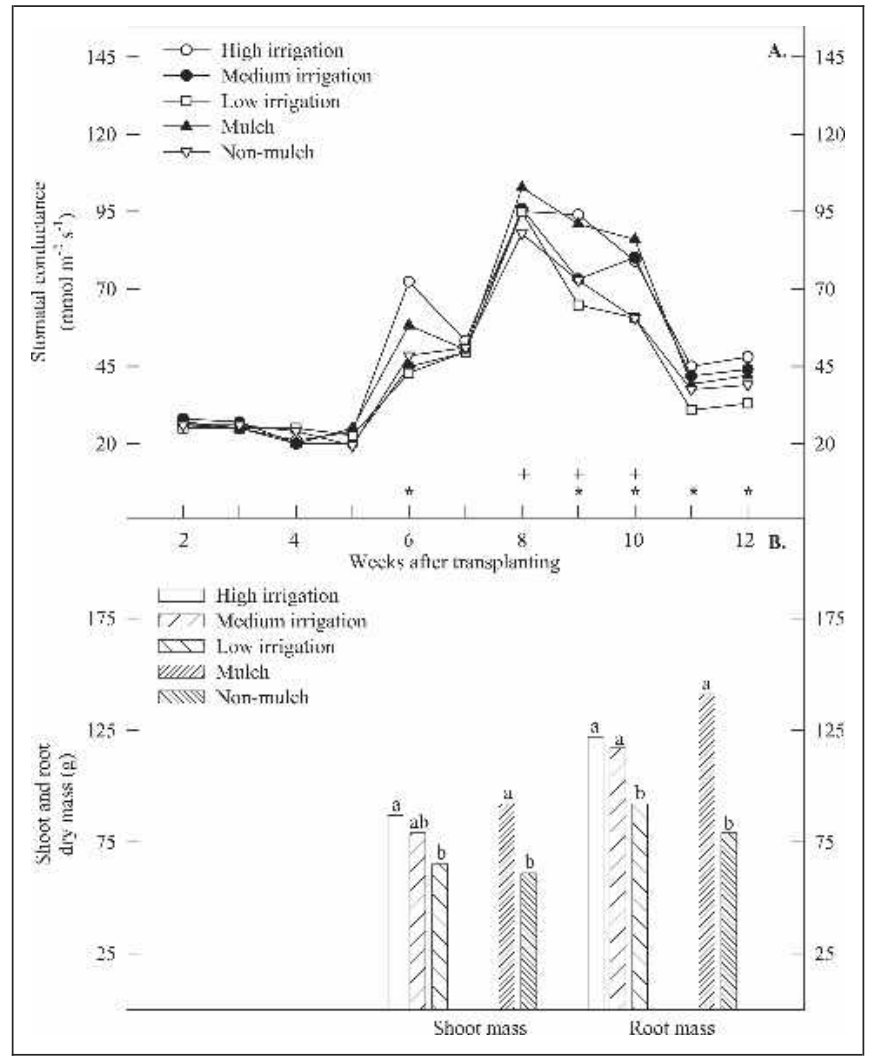

Figure 3. Effect of irrigation volume and mulch on (A) stomatal conductance and (B) growth of containerized Vanhoutte spirea (Spiraea $\times$ vanhouttel) transplants grown in Dallas, Texas during 2001. Asterisks or plus signs (A) indicate treatment effects at the $1 \%, 5 \%$, or $10 \%$ level by $\mathrm{F}$ test for irrigation volume and mulch, respectively (each point is the mean of 18 (irrigation treatment) or 27 (mulch treatment) measurements). Different letters (B) indicate effect of irrigation volume or mulch on plant growth (least significant difference, $P \leq 0.05$ ).

data indicate photinia transplants under medium irrigation had greater root mass than transplants grown under high or low irrigation. Mulch did not influence shoot or root mass of photinia transplants (Figure 5).

\section{DISCUSSION}

Benefits of organic mulch in landscapes are well documented. Organic mulches moderate soil temperature (Montague et al. 2000a), increase soil moisture (Litzow and Pellett 1983), reduce weed competition (Greenly and Rakow 1995), and have a positive influence on growth for many tree species (Fraedrich and Ham 1982; Watson 1988; Watson and Kupkowski 1991; Greenly and Rakow 1995; Kraus 1998). However, until now, limited research investigating the positive influence organic mulch has on shrub establishment in landscape situations has been conducted. Previously, Hild and 


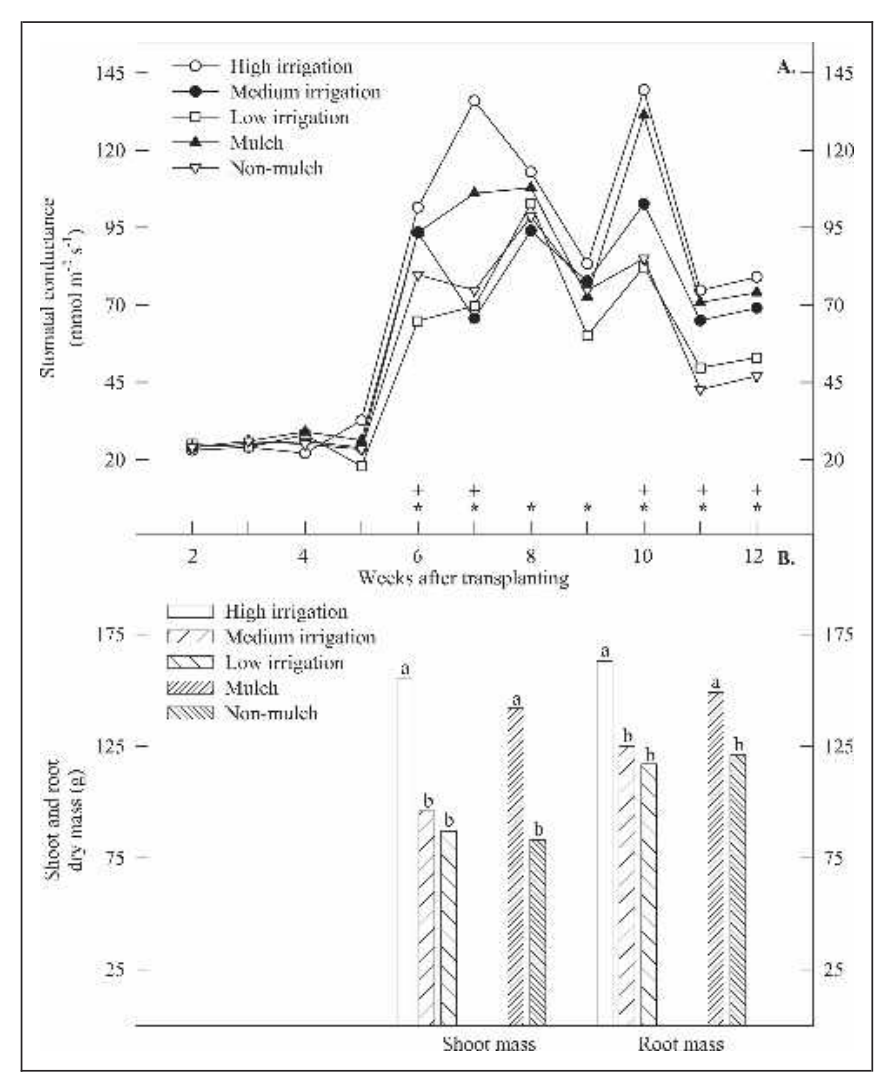

Figure 4. Effect of irrigation volume and mulch on (A) stomatal conductance and (B) growth of containerized forsythia (Forsythia $\times$ intermedia 'Lynwood') transplants grown in Dallas, Texas, during 2001. Asterisks or plus signs (A) indicate treatment effects at the $1 \%, 5 \%$, or $10 \%$ level by $\mathrm{F}$ test for irrigation volume and mulch, respectively (each point is the mean of 18 (irrigation treatment) or 27 (mulch treatment) measurements). Different letters (B) indicate effect of irrigation volume or mulch on plant growth (least significant difference, $P \leq 0.05$ ).

Morgan (1993) investigated effects of two organic mulch (pine bark nuggets) depths ( $7.5 \mathrm{~cm}$ and $15 \mathrm{~cm}$ [3 in and 6 in]) on crown growth of five southwestern shrub species [cliffrose (Cowania mexicana), curlleaf mahogany (Cercocarpus ledifolius), desert olive (Forestiera neomexicana), Apache plume (Fallugia parodoxa), and winterfat (Ceratoides lanata)] planted in a semiarid climate (Lubbock, TX). They report mulch treatments did not influence plant growth and suggest species native to semiarid regions may not benefit from mulch when placed in irrigated landscapes. Also in a semiarid climate (Northern Utah), Montague et al. (1998) found pine bark mulch $(10 \mathrm{~cm}[4 \mathrm{in}])$ created adverse environmental conditions (increased sensible heat flux, lower RH, greater evaporative demand) near the mulch surface when compared with environmental conditions near the surface of wellwatered Kentucky bluegrass (Poa pratensis) turf. As a result

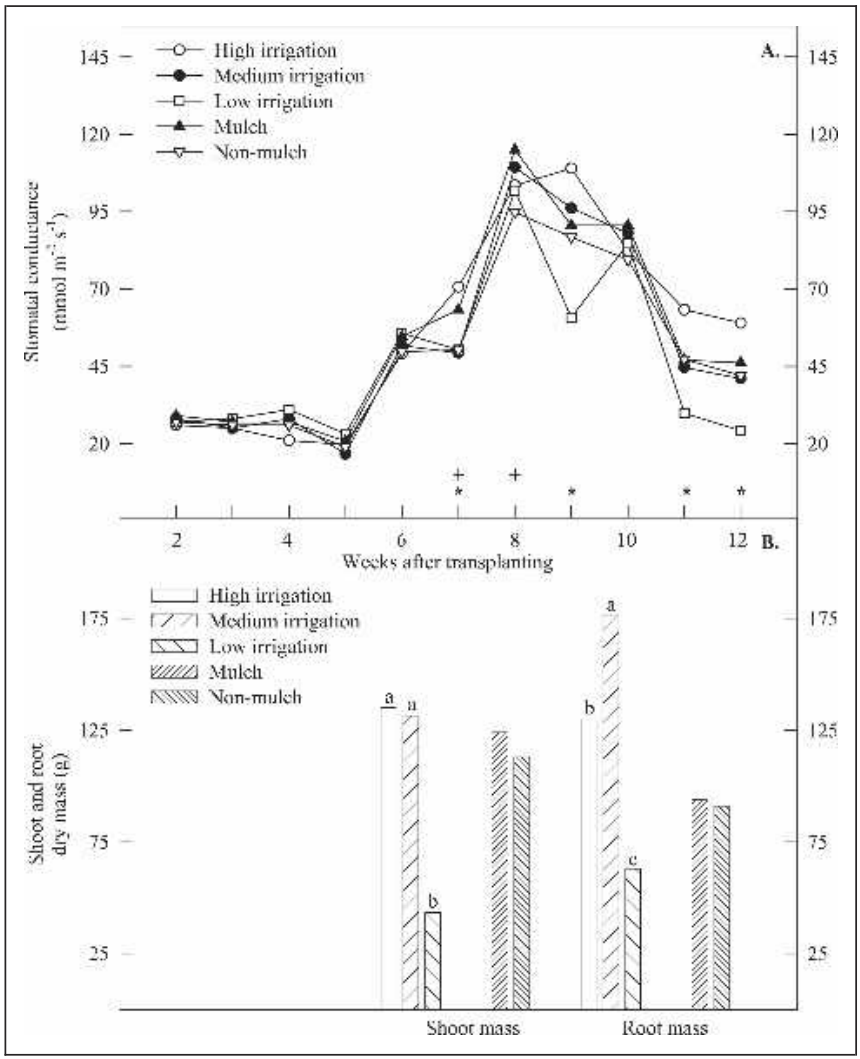

Figure 5. Effect of irrigation volume and mulch on (A) stomatal conductance and (B) growth of containerized photinia (Photinia $\times$ fraseri) transplants grown in Dallas, Texas, during 2001. Asterisks or plus signs (A) indicate treatment effects at the $1 \%, 5 \%$, or $10 \%$ level by $\mathrm{F}$ test for irrigation volume and mulch, respectively (each point is the mean of 18 (irrigation treatment) or 27 (mulch treatment) measurements). Different letters (B) indicate effect of irrigation volume or mulch on plant growth (least significant difference, $P \leq \mathbf{0 . 0 5}$ ).

of adverse growing conditions over the mulch surface, containerized shrubs of skunkbush sumac (Rhus trilobata) had lower GS, water loss, and photosynthetic rate when compared with shrubs grown over turf.

In the current study, we found greater gas exchange and growth for plants grown over mulch when compared with plants grown over bare soil. Zajicek and Heilman (1991) investigated gas exchange of several containerized crapemyrtle cultivars grown over organic mulch, bare soil, and turf in a similar climate (College Station, TX) as our study. They report shrubs grown over $8 \mathrm{~cm}$ (3.2 in) of pine bark mulch had greater water loss when compared with plants grown over turf and bare soil surfaces. Climatic factors have a significant influence on plant gas exchange and growth (Montague et al. 2000a). Evaporative demand placed on plants is largely a factor of RH, air temperature, and leaf temperature (Jones 
1992). If RH is low (like in a semiarid climate), there is greater evaporative demand and many species respond by partial stomatal closure (Montague et al. 1998), which decreases GS, water loss, and photosynthetic rate. In climates with increased $\mathrm{RH}$, evaporative demand placed on plants is generally less when compared with evaporative demand placed on plants in arid or semiarid climates (Montague et al. 1998, 2000a). Therefore, plants in our study (in a climate with high RH) were likely subjected to lower evaporative demand throughout the day. This response in combination with benefits of organic mulch (increased soil moisture, moderate soil temperatures, and so on) likely allowed plants over mulch to have greater GS, water loss, photosynthetic rate (Hinckley et al. 1978), and growth when compared with plants grown without the benefits of organic mulch.

Water requirements of landscape plants have been estimated over several years and by various methods (Sachs et al. 1975; Paine et al. 1992; Montague et al. 2004; Shaw and Pittenger 2004). Montague et al. (2004) found total daily ETO taken over an extended period of time to be a limited but valuable tool to estimate water needs of recently transplanted tree species. This appears true for plant species used in this study. We found shrubs irrigated at $75 \%$ ETO produced gas exchange and growth generally similar to shrubs irrigated at the $100 \%$ ETO level (Figures 2-5). Of species tested, only forsythia transplants irrigated at the 100\% ETO level had greater gas exchange and growth when compared with transplants irrigated at the 75\% ETO level (Figure 4).

Lockett et al. (2002) reports several ornamental species previously established in the landscape [pink evening primrose (Oenothera speciosa), prairie verbena (Verbena bipinnatifida), red yucca (Hesperaloe parviflora), ceniza (Leucophyllum frutescens), and ruellia (Ruellia nudiflora)] irrigated over the growing season at $60 \%$ ETO had acceptable appearance and growth. Shaw and Pittenger (2004) investigated aesthetic quality of 30 ornamental species (also previously established in the landscape) planted into landscapes and irrigated at three irrigation levels $(36 \%, 18 \%$, and $0.0 \%$ ETO). They found many of the species performed well (high aesthetic quality) at the $36 \%$ and $18 \%$ ETO irrigation levels. Although not statistically analyzed, we found after one growing season all plants (regardless of species, irrigation level, or mulch treatment) had aesthetic qualities that would likely be acceptable in landscape situations (Lockett et al. 2002).

\section{CONCLUSIONS}

Planting containerized crapemyrtle, spirea, and photinia plants in landscape beds with mulch and irrigating at the $75 \%$ ETO irrigation level produced similar gas exchange and growth as transplants grown with mulch and irrigated at the $100 \%$ ETO irrigation level. However, during the growing season, irrigation at the medium rate conserved over 1,700 L (450 gal) of water. Compared with the high irrigation rate, forsythia transplants had lower gas exchange and growth at the low irrigation rate. In general, planting with mulch appeared to increase gas exchange and growth of all transplants. Although all transplants performed well at greater irrigation rates, we found using organic mulch and irrigating during the initial growing season at 50\% ETO produced plants with acceptable growth and aesthetics for landscape situations. These findings should be useful for landscape irrigation scheduling and for incorporating water conservation into landscape maintenance programs.

Acknowledgments. Support for this project was provided in part by a grant from the College of Agricultural Sciences and Natural Resources, Texas Tech University. Manuscript No. T-4-577 of the College of Agricultural Sciences and Natural Resources. Mention of a trademark, proprietary product, or vendor does not constitute a guarantee or warranty of the product by the author or Texas Tech University and does not imply its approval to the exclusion of other products or vendors that also may be suitable.

\section{LITERATURE CITED}

Allen, R.G. 2000. REF-ET: Reference evapotranspiration calculation software. Windows Version 2.01.17. Department of Biological and Agricultural Engineering, University of Idaho, Moscow.

Arnold, M.A., G.V. McDonald, and D.L. Bryan. 2005. Planting depth and mulch thickness affect establishment of green ash (Fraxinus pennsylvanica) and bougainvillea goldenraintree (Koelreuteria bipinnata). Journal of Arboriculture 31:163-170.

Costello, L., and J.L. Paul. 1975. Moisture relations in transplanted container plants. HortScience 10:371-372.

Ferguson, B.K. 1987. Water-conservation methods in urban landscape irrigation: an exploratory overview. Water Resources Bulletin 23:147-152.

Fraedrich, S.W., and D.L. Ham. 1982. Wood chip mulching around maples: effect on tree growth and soil characteristics. Journal of Arboriculture 8:85-89.

Greenly, K.M., and D.A. Rakow. 1995. The effect of wood mulch type and depth on weed and tree growth and certain soil parameters. Journal of Arboriculture 21:225-232.

Hensley, D.L., R.E. McNiel, and R. Sundheim. 1988. Management influences on growth of transplanted Magnolia grandiflora. Journal of Arboriculture 14:204-207.

Hild, A.L., and D.L. Morgan. 1993. Mulch effects on crown growth of five southwestern shrub species. Journal of Environmental Horticulture 11:41-43.

Hinckley, T.M., R.G. Aslin, R.R. Aubuchon, C.L. Metcalf, and J.E. Roberts. 1978. Leaf conductance and photosynthesis in four species of the oak-hickory forest type. Forest Science 24:73-84.

Jensen, D.T., G.H. Hargreaves, B. Temesgen, and R.G. Allen. 1997. Computation of ETO under non-ideal conditions. 
Journal of Irrigation and Drainage Engineers 123: 394-400.

Jones, H.G. 1992. Plants and microclimate: A quantitative approach to environmental plant physiology. 2nd Edition. Cambridge University Press, Cambridge, U.K.

Kraus, H.T. 1998. Effects of mulch on soil moisture and growth of desert willow. HortTechnology 8:588-590.

Litzow, M., and H. Pellett. 1983. Influence of mulch materials on growth of green ash. Journal of Arboriculture 9:7-11.

Lockett, L. T. Montague, C. McKenney, and D. Auld. 2002. Assessing public opinion on water conservation and water conserving landscapes in the semiarid Southwestern United States. HortTechnology 12:392-396.

McDaniels, T.L., L.J. Axelrod, and N. Cavanagh. 1998. Public perception regarding water quality and attitudes toward water-conservation in the lower Fraser Basin. Water Resources Research 34:1299-1306.

Montague, T., R. Kjelgren, and L. Rupp. 1998. Surface energy balance affects gas exchange of three shrub species. Journal of Arboriculture 24:254-262.

- 2000a. Surface energy balance affects gas exchange and growth of two irrigated landscape tree species in an arid climate. Journal of the American Society for Horticultural Science 125:299-309.

- 2000b. Gas exchange and growth of two transplanted, field-grown tree species in an arid climate. HortScience 35:763-768.

Montague, T., R. Kjelgren, R. Allen, and D. Wester. 2004. Water loss estimates for five recently transplanted landscape tree species in a semi-arid climate. Journal of Environmental Horticulture 22:189-196.

Paine, T.D., C.C. Hanlon, D.R. Pittenger, D.M. Ferrin, and M.K. Malinoski. 1992. Consequences of water and nitrogen management on growth and aesthetic quality of drought-tolerant woody landscape plants. Journal of Environmental Horticulture 10:94-99.

Pittenger, D.R., D.A. Shaw, D.R. Hodel, and D.B. Holt. 2001. Responses of landscape groundcovers to minimum irrigation. Journal of Environmental Horticulture 19:78-84.

Sachs, R.M., T. Kretchun, and T. Mock. 1975. Minimum irrigation requirements for landscape plants. Journal of the American Society for Horticultural Science 100: 499-502.

Shaw, D.A., and D.R. Pittenger. 2004. Performance of landscape ornamentals given irrigation treatments based on reference evapotranspiration. Acta Horticulturae 664: 607-614.

Spinti, J.E., R.S. Hilaire, and D. VanLeeuwen. 2004. Balancing landscape preferences and water conservation in a desert community. HortTechnology 14:72-77.

Staats, D., and J.E. Klett. 1995. Water conservation potential and quality of non-turf groundcovers versus Kentucky bluegrass under increasing levels of drought stress. Journal of Environmental Horticulture 13:181-185.

Stabler, L.B., and C.A. Martin. 2000. Irrigation regimens differentially affect growth and water use efficiency of two southwest landscape plants. Journal of Environmental Horticulture 18:66-70.

Urbano, C.C. 1990. The great disappearing act of usable American water. American Nurseryman 163:52-55.

Watson, G.W. 1988. Organic mulch and grass competition influence tree root development. Journal of Arboriculture 14:200-203.

Watson, G.W., and G. Kupkowski. 1991. Effects of a deep layer of mulch on the soil environment and tree root growth. Journal of Arboriculture 17:242-245.

Whitcomb, C.E. 1980. Effects of black plastic and mulches on growth and survival of landscape plants. Journal of Arboriculture 6:10-12.

Wright, A.N. S.L. Warren, F.A. Blazich, and U. Blum. 2004. Root and shoot growth periodicity of Kalmia latifolia 'Sarah' and Ilex crenata 'Compacta'. HortScience 39: 243-247.

Zajicek, J.M., and J.L. Heilman. 1991. Transpiration by crape myrtle cultivars surrounded by mulch, soil, and turfgrass surfaces. HortScience 26:1207-1210.

Thayne Montague (corresponding author)

Associate Professor

Department of Plant and Soil Science

Texas Tech University

Lubbock, TX 79409-2122, U.S.

thayne.montague@ttu.edu

Cynthia McKenney

Associate Professor

Department of Plant and Soil Science

Texas Tech University

Lubbock, TX 79409-2122, U.S.

Michael Maurer

Assistant Professor

Department of Agriculture

Stephen F. Austin University

Nacogdoches, TX 75962, U.S.

Brian Winn

Former Graduate Research Assistant

Department of Plant and Soil Science

Texas Tech University

Lubbock, TX 79409-2122, U.S.

Résumé. Sous plusieurs climats, l'irrigation des arbustes durant leur reprise est critique pour la croissance à long terme et la survie. Néanmoins, peu de recherche a été menée pour déterminer les be- 
soins en irrigation d'arbustes produits en pot et nouvellement transplantés. Durant deux saisons de croissance, nous avons vérifié la croissance et les échanges gazeux de Lagerstroemia indica, de Forsythia $\times$ intermedia 'Lynwood', de Spiraea $\times$ vanhouttei et de Photinia $\times$ fraseri nouvellement transplantés dans des plates-bandes avec et sans paillis organique. Après la transplantation, les végétaux ont été irrigués deux fois par semaine selon les taux suivants: 100, 75 et $50 \%$ d'évapotranspiration de référence $\left(\mathrm{ET}_{0}\right)$. En général, chaque plant, avec ou sans paillis, ayant reçu 100 ou $75 \%$ d'irrigation sur la base de l'ET ${ }_{0}$ avait une conductance stomatale plus élevée, et ce comparativement aux plants, avec ou sans paillis, ayant reçu une irrigation plus faible. Le taux de croissance des plants suivait également des tendances similaires. Néanmoins, il importe de noter que tous les plants ont survécu et ont semblé être en bonne santé durant toute la saison de croissance. Même les plants ayant reçu une irrigation de $50 \%$ d'ET ${ }_{0}$ étaient esthétiquement beaux et avaient une croissance acceptable en aménagement paysager. Ces découvertes devraient être utiles pour la planification du calendrier d'irrigation et pour les gestionnaires de systèmes d'irrigation qui incorporent la conservation de l'eau dans leur programme d'entretien de leur aménagement paysager.

Zusammenfassung. In vielen Klimaten ist das Bewässern von Büschen während der Anpflanzzeit für das Überleben am Standort entscheidend. Dennoch wurde bislang wenig Forschung durchgeführt, um die Bewässerungsanforderungen für frisch gepflanzte Container-Ware zu untersuchen. Während zwei Wachstumsperioden untersuchten wir den Gasaustausch und Wachstum von frisch gepflanzten Containerpflanzen, die in Pflanzbeete mit und ohne organischen Mulch gesetzt wurden. Nach der Verpflanzung wurden die Pflanzen zweimal die Woche mit den folgenden Raten bewässert: 100, 75 und $50 \%$ in Bezug auf die Evatranspiration (ETo). Allgemein hatten jedes Jahr die Pflanzen mit dem Mulch und einer Bewässerung mit 100 bis $75 \%$ ETo eine größere stomatale Leit- fähigkeit als die Pflanzen ohne Mulch und mit weniger Bewässerung. Das Wachstum der Pflanzen folgte einem ähnlichen Trend. Dennoch ist es wichtig zu bemerken, dass alle Pflanzen überlebten und während der Wachstumssaison gesund blieben. Sogar die Pflanzen mit $50 \%$ ETo waren ästhetisch ansprechend und hatten ein akzeptables Wachstum für Landschaftssituationen. Diese Ergebnisse können nützlich sein für die Gestaltung von Bewässerungsplänen und für Bewässerungsmanager, die Wasserbevorratung in ihr Landschaftskonzept einarbeiten müssen.

Resumen. En muchos climas el riego de los arbustos durante el establecimiento es crítico para el crecimiento y supervivencia. Sin embargo, se ha hecha poca investigación para conocer los requerimientos de riego de arbustos en contenedor recién trasplantados. Durante dos estaciones de crecimiento, se investigó el intercambio de gases y el crecimiento de astronómicas (Lagerstroemia indica 'Victor'), forsytia (Forsythia $\times$ intermedia 'Lynwood'), Vanhoutte espirea (Spiraea $\times$ vanhouttei), y potinia (Photinia $\times$ fraseri) crecidas en contenedor y transplantadas en camas de crecimiento con y sin mulch orgánico. Después del trasplante, las plantas fueron regadas dos veces por semana a las siguientes tasas: 100, 75 y $50 \%$ de la evapotranspiración de referencia (ETO). En general, cada año los transplantes con mulch y los trasplantes que recibieron riego con base en 100 o $75 \%$ de ETO tuvieron mayor conductancia estomacal (GS) comparada con trasplantes sin mulch y trasplantes recibiendo menos riego. El crecimiento de los trasplantes siguió tendencias similares. Sin embargo, es clave anotar que todos los trasplantes sobrevivieron y aparecieron saludables a través de la estación de crecimiento. Aunque los trasplantes que recibieron 50\% de ETO fueron estéticamente agradables y tuvieron crecimiento aceptable para las condiciones del terreno. Estos hallazgos deberán ser útiles para la programación del riego y para los manejadores de riego incorporando la conservación del agua en sus programas de mantenimiento. 